\title{
OCCURRENCE OF LOG-DWELLING INVERTEBRATES IN REGENERATION AND OLD-GROWTH WET SCLEROPHYILL FOREST IN SOUTHERN TASMANIA
}

\author{
by Robert J. Taylor
}

(with two tables and one text-figure)

TAYLOR, R.J. IG)() (31:x): Occurrence of log-dwelling invertebrates in regeneration and old-growth wet sclerophyll forest in southern Tasmania. Pap. Proc. R. Soc. Tasm. 124(1): 27-34. https://doi.org/10.26749/rstpp.124.1.27 ISSN (0)8()-47(0). Tasmanian Forestry Comrnission. 30) Patrick Street. Hobart. Tasmania, Australia 70)(0).

A list of colcopteran, large collembolan, centipede, millipede and molluscan species associated with rotting logs was compiled for ain old-growth Eucalyptus obliqua wet sclerophyll forest and adjacent 19-year-old regeneration in southern Tasmania. A total of 67 species were found, 40) occurring in both areas, 53 in old-growth forest and 54 in the regenerated area. Of the species found in only one of the areas, nearly all occurred in one or two samples only, so no conclusion about their absence from the other area can be made. Two rarely collected species of beetles were recorded only in the old growth forest. Conservation of log-dwelling invertebrates in production forests is discussed.

Key Words: rotting logs, invertebrates, forestry, conservation.

\section{INTRODUCTION}

The development of strategies for conservation of invertebrates is impeded by the huge number of species, many undescribed, and the scant information on their distribution and ecology. Because of this, a strategy for conserving invertebrates by conservation of different vegetation types has been advocated (Marks 1972, New 1984). However, the distribution of many invertebrate species is known to be more restricted than that of the vegetation types in which they occur.

An analysis of the Tasmanian invertebrate fauna by Greenslade (1985) attempted a finer resolution of invertebrate habitats to aid in their conservation. Her analysis suggested that logs in a late stage of decay might be an important habitat for many species of invertebrates restricted to Tasmania. She reported that many entomologists had expressed concern about the effect of forest operations on logs as a habita' in invertebrates. They believed that charring of logs due to regeneration burning and drying out of these logs after the forest canopy was removed would make them unsuitable as a habitat for invertebrates.

$\Lambda$ wide examination of the effects of logging on log-dwelling invertebrates would require a long and detailed stucly. This paper reports on the occurrence of selected groups of invertebrates associated with rotting logs at one wet sclerophyll site in southern Tasmania, where 19-year-old regeneration forest is adjacent 10 old-growth forest, and also on the results of a preliminary examination of the magnitude of differences between logged and unlogged areas.

\section{STUDY AREA}

The study area is situated along Edwards Road in the Huon River Valley approximately $500 \mathrm{~m}$ from the river (TASMAP 1:100000, Huon 798310 ). Aspect is westerly with gentle slopes. Elevation ranges from $110-130 \mathrm{~m}$ in the north of the site to $80-100 \mathrm{~m}$ in the south. Annual rainfall is in the range $1000-1250 \mathrm{~mm}$ with a broad winter maximum.

Both old growth forest and regeneration occur alongside the road at this site. Eucalyptus obliqua dominates the canopy in both forests. The oldgrowth forest contains scattered large trees, some with a basal diameter greater than $2.5 \mathrm{~m}$, which may be over 400 years old. Occasional groups of spars, 165-170 years old, occur together with dense pole stands originating from a wildfire in 1906 . Two different understoreys are found. Rainforest is present in patches, comprising multi-age myrtle (Nothofagus cunninghamii) with Anodopetalum biglandulosum, Anopterus glandulosus, Atherosperma moschatum, Eucryphia lucida and Phyllocladus aspleniifolius. Ferns include Blechnum wattsii, Dicksonia antarcicica, Histiopteris incisa and Polystichum proliferum. Covering a smaller area than the rainforest understorey are patches of Eucalyptus obliqua poles over seedling myrtles ( $N$. cunninghamii) with Acacia 
dealbata, A melanoxylon, Coprosma quadrifida, Olearia argophylla, Pittosporum bicolor and Pomaderris apetala.

A similarly variable understorey may have covered the regenerated block before logging, as small volumes of myrtle, blackwood and leatherwood were harvested. The area was logged from 1965-67 and regeneration burning was carried out in March 1969. Regeneration was largely natural but was heavily browsed, requiring additional "fill-in" sowing and planting. The regenerated block has been left untreated since spring 1971. Today the block carries E. obliqua regrowth under a few old-growth stags. Regrowth density varies greatly, and parts are poorly stocked with eucalypts. Under the poles the vegetation consists mainly of Acacia dealbata, $A$. melanoxylon, A. verticillata and Pomaderris apetala. Also present are Dicksonia antarctica, Gahnia grandis, Monotoca glauca and Pteridium esculentum.

Eucalypts make up the largest volume of rotting logs in both sites but wattle and rainforest logs are also present. All logs in the regeneration area were charred or partially burned in the regeneration fire and a high proportion of eucalpyt logs in the oldgrowth were charred - as standing trees - in the 1906 fire, which established the pole patches. Many of the rainforest logs in the old-growth block are deeply invaded by roots of the regrowth and as a result are relatively dry. Logs in the regeneration, on the other hand, are usually covered with bracken and leaf litter, and are generally wetter than similar-sized $\log$ s in the old-growth block.

\section{METHODS}

Fieldwork was carried out between 15 March and 7 April 1988. This period was extremely dry, with the summer rainfall at ncarby Geeveston being the lowest on record. An area of $0.1-0.2$ ha was searched per day, with old-growth and regeneration blocks being sampled on alternate days. All old, well-rotted $\operatorname{logs}$ and well-rotted portions of "recent" $\operatorname{logs}$ within the selected area were searched. Patches were $20-300 \mathrm{~m}$ from Edwards Road and were scattered through the forest with a bias toward deeper shade. The total area sampled was about 1.5 ha in each block.

Typically a $2 \mathrm{~m}$ long section was examined regardless of $\log$ diameter. In several cases, collections were made at a number of well-spaced points along each $\log$ and these were recorded as different samples. For each sample, log species (where recognisable) and approximate originat diameter were noted. Different types of rot could be discerned. However, it was heyond the scope of the present study to detail the habitat preferences of individual species. Logs were broken open with a large chisel and carefully searched for invertcbrates. Stumps, the undersides of logs lying on the ground and crevices on log tops and sides were also investigated. Only species of Mollusca (snails), Chilopoda (centipedes), Diplopoda (millipedes), Coleoptera (beefles) and large Collembola (springtails) were collected. These groups were selected as they were easily collected, morphological types were readily discernible in the field and taxonomists were available to identify the material (or at least to separate out different species). Specimens were removed by handpicking. Normally only one or two individuals of each species were taken. Each sample thus generated a list of species present.

Specimens were taken live from the study area for processing later the same day. Adult beetles were killed by freezing and pinned. Snails were drowned overnight in weak aqueous phenol, then transferred to $50 \%$ ethanol $/ 5 \%$ glycerol. Beetle larvae and pupae were killed in $30 \%$ ethanol, myriapods and collembolans in $70 \%$ ethanol.

The numbers of logs of each tree species in the old-growth and regenerated sites are shown in table 1. Chi-square analysis was used to compare the frequency of occurrence of species in logs in the old-growth and the regenerated forest and to compare the use of logs from different tree species. Only those species which were found in ten or more logs were examined in these analyses.

\section{RESULTS}

\section{Species Totals and Sampling Effort}

Figure 1 shows the number of species collected as a function of the number of days spent sampling. The number of days is not directly related to sampling effort as two people collected on the first day in each area whereas on other days only one person was sampling. In the regeneration an asymptote had been reached by the end of the sampling; for the old growth only a very minor increase in number was occurring with extra sampling. Thus, it is likely that the sampling program had detected nearly all of the species which would have been found using the particular sampling methods employed for that particular time. The very dry conditions may have diminished 


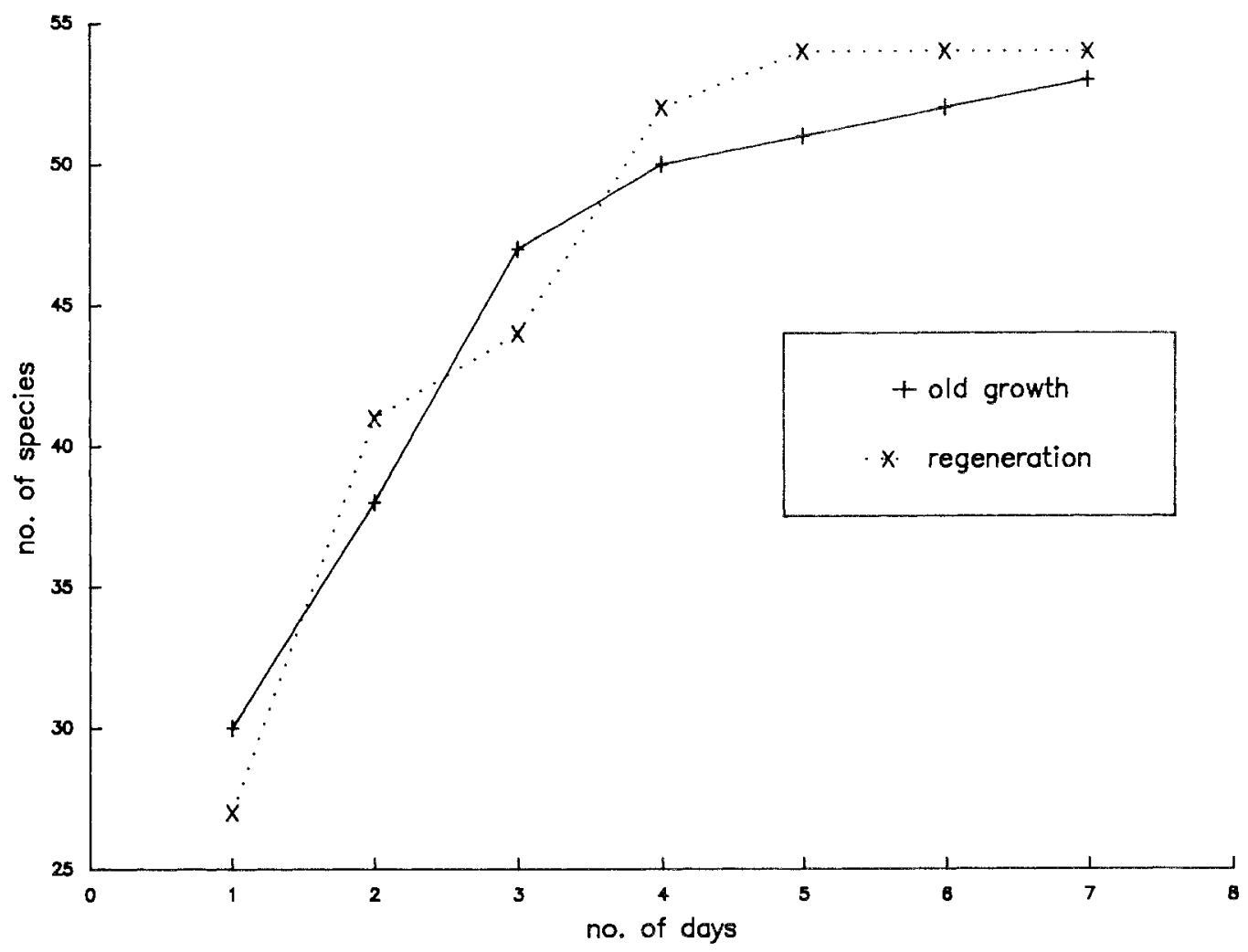

FIG. I Relationship between the number of days spent sampling and number of species collected.

TABLE 1

Types of Logs Sampled in Regeneration and Old-Growth Areas

\begin{tabular}{lccccccr}
\hline & Eucalypt & Myrtle & Sassafras & Wattle & Leatherwood & Unknown & Total \\
\hline Old-growth (unlogged) & 29 & 11 & 5 & 0 & 1 & 7 & 5 \\
Regenerated (logged) & 28 & 13 & 1 & 2 & 0 & 8 & 52 \\
Total & 57 & 24 & 6 & 2 & 1 & 15 & 105 \\
\hline
\end{tabular}


species tolals, due to some invertebrates leaving $\log$ to shelter in soll crevices or moist leaf litter. Experience elsewhere suggests that under wetter conditions more specimens per sample would have been recovered (R. Mesibov, pers. comm.).

\section{Comparison of Areas}

Table 2 lists the "species" found and their frequencies of occurrence in logs in the two areas. One or two of the "species" categories may comprise several species (e.g. unidentified Tenebrionidae). Of the 67 species recognised, 53 occurred in old-growth forest and 54 in regeneration; 40 species occurred in both areas. Eighteen species occurred in numbers large enough to allow statistical analysis; all of these were found in both areas. The frequencies of occurrence of three centipede, three millipede, four beetle and two collembolan species did not differ significantly between the two areas. One snail, one centipede and one collembolan species were more frequent in logs sampled in the regenerated block, and one centipede and two millipede species were more frequent in the old-growth. One millipede and 12 beetle species occurred only in the old-growth area; 12 of these were found in only one or two samples; hence it cannot be concluded with any certainty that they were absent from the regeneration area. The one exception was the carabid beetle Chlynus ater, which was found in seven samples, but this occurred in the infrequently searched zone under rotting logs. Four snail, three millipede, six beetle and one collembolan species were found only in the regeneration; of these, the snail Allocharopa legrandi occurred in five samples and the millipede Polydesmida species D in three; all others occurred in only one or two logs.

\section{Use of Tree Species}

The 18 species occurring in ten or more samples were examined for any preferences shown for the species of $\log$ inhabited. Occurrences in noneucalypt logs were grouped, due to small sample sizes. No significant differences were found between the frequency of occurrence of species in eucalypt and non-eucalypt $\operatorname{logs}$ and that expected on the basis of their frequency of being sampled.

\section{Notes on the Species found}

Notes on the distribution and abundance of the snail (Smith \& Kerchaw 1981), beetle (P. McQuillan and D. Bashford, pers. comm. and collembolan (Greenslade, in press) species are given in table 2.

\section{Cenfipedes (Mesibow 1986)}

Each of the six species collected has previously been recorded from the Hum district. All are widespread in Tasmania and can be locally abundant, especially as juveniles in leaf litter. The poor state of taxonomic and distributional knowledge makes it impossible to say whether any of the species are restricted to Tasmania within Australia. Centipedes apparently identical to Cryptops megalopora, Henicops masulata and Zelanion antipodus occur in New Zealand.

\section{Millipedes}

Tasmania's millipede fauna is very poorly known. Only a handful of species have been well described, and no distributions have yet been mapped. Assignment to higher taxa was based on descriptions and biogeographic information in Hoffman (1982). Only one of the 14 presumed species could be identified with confidence. Lissodesmus modestus has previously been collected near Russell Falls in Mount Field National Park and on Mount Wellington (Jeekel 1984).

\section{DISCUSSION}

A large proportion of species in the groups examined were present in both areas. Therefore, differences between the forest types in the fauna of this microhabitat are likely to be subte and demand high levels of sampling intensity and replication Consequently, the results of this study can only serve to guide future research and cannot be used to assess the effects of logging on the invertebrate groups examined. Given the similarity in species diversity between treatments, it is arguable that burning of the outside of a $\log$ does not cause it to become useless inside as a habitat for all invertebrates. The same conclusion has been reached by Mesibov (1988). Some species, however, may be adversely affected by burning of logs. The oldgrowth forest was burnt by a wildfire about 80 years ago. Thus, if a cerlain species was very sensitive to the effects of fire it could have also 
TABLE 2

Occurence of Invertebrates in Logs from Old-Growth and Regeneration Forest

\section{Species}

Caryodidae

Caryodes ditresnil

Charopidate

Allocharopa hegrandi

Mulathena fordei

Roblinella gadensis

Stenacapha hamiltoni

Cystopeltidae

Cystopelta petterdi

Helicarionidae

Helicarion chvieri

Rhytididae

Tasmaphena sinclairi

\section{CHLLOPODA}

?Chilenophilidae

Tasmanophilus opinatus

Zelamion amipodus

Cryptopidae

Cryptops megaloporat

Cryptops sp.

Henicopidac

"anopsobiine sp. 2"

Henicops maculata

\section{DIPLOPODA}

Order Chordenmatida

species $A$

species $B$
Old-growth

(5.3 logs)

Regeneration

(52 logs)

\section{Difference}

between sites:

\section{Notes}

Endemic, widespreat

Endemic, known only mom wet sclerophyll in $s$ Tasmania

Western and SE " $\Gamma$ asmania Endemic, previously only recorded from $N$ and $N W$

Endemic, widespread

Widespread

Endemic, widespread

Endemic, widespread

$<0.05$

Order Polydesmida

Lissodesmus modestu.

Lissodesmits sp.

Asphalidesmus sp.

species A

species B

species (

species D

species $E$

species $F$

Order Polyonniidat

species A

Order Sphaerotheriida species $A$ 


\begin{tabular}{|c|c|c|c|c|}
\hline Species & $\begin{array}{l}\text { Old-growth } \\
\text { (53 logs) }\end{array}$ & $\begin{array}{l}\text { Regeneration } \\
\quad(52 \operatorname{logs})\end{array}$ & $\begin{array}{c}\text { Difference } \\
\text { between sites* }\end{array}$ & Notes \\
\hline \multicolumn{5}{|l|}{ COLEOPTERA } \\
\hline \multicolumn{5}{|l|}{ Alleculidae } \\
\hline species A & 1 & - & - & \\
\hline \multicolumn{5}{|l|}{ Carabidae } \\
\hline Chlynus ater & 7 & - & - & Widespread \\
\hline Hypharpax sp. & 1 & - & - & $\begin{array}{l}\text { Widespread, usually in open } \\
\text { habitats such as grasslands }\end{array}$ \\
\hline Notonomus sp. & 2 & 1 & - & Widespread in wet forests \\
\hline Percosoma carenoides & 2 & - & - & $\begin{array}{l}\text { Endemic, occurs in large } \\
\text { patches of wet forest; } \\
\text { largest Brosciniae in the } \\
\text { world }\end{array}$ \\
\hline Promecoderus tasmanicus & - & 1 & - & $\begin{array}{l}\text { Endemic, wet sclerophyll } \\
\text { forest in S Tasmania }\end{array}$ \\
\hline trechine sp. A & 1 & 2 & - & Damp habitats \\
\hline broscine sp. A (larvae) & 2 & 1 & - & \\
\hline Unidentified larvae & 1 & 1 & - & \\
\hline \multicolumn{5}{|l|}{ Cerambycidae } \\
\hline Dorcadida biocularis & 1 & - & - & $\begin{array}{l}\text { Endemic(?), widespread, } \\
\text { occurs where dense litter }\end{array}$ \\
\hline ?Toxeutes arcuatus & - & 1 & - & Widespread in forests \\
\hline \multicolumn{5}{|l|}{ Chrysomelidae } \\
\hline Chrysophtharta agricola & - & 1 & -- & $\begin{array}{l}\text { Widespread in forests and } \\
\text { woodlands }\end{array}$ \\
\hline C. bimaculata & 1 & - & - & Widespread \\
\hline Paropsis sp. & - & 1 & - & Genus widespread \\
\hline \multicolumn{5}{|l|}{ Coccinellidae } \\
\hline Cleobora mellyi & - & 1 & - & $\begin{array}{l}\text { Widespread, predator of } \\
\text { beetle eggs }\end{array}$ \\
\hline \multicolumn{5}{|l|}{ Cucujidae } \\
\hline Prostomis atkinsoni & 4 & 9 & NS & $\begin{array}{l}\text { Widespread, found under } \\
\text { bark on freshly fallen logs }\end{array}$ \\
\hline \multicolumn{5}{|l|}{ Curculionidae } \\
\hline Poropterus sp. & 1 & - & - & Widespread \\
\hline cossonine sp. & 1 & 1 & - & Widespread group \\
\hline \multicolumn{5}{|l|}{ Elateridae } \\
\hline Crepidomenus sp. & 1 & - & - & Widespread \\
\hline Elatichrosis trisulcata & 12 & 15 & NS & Wet forests \\
\hline \multicolumn{5}{|l|}{ Lucanidae } \\
\hline Lissotes cancroides & 30 & 20 & NS & $\begin{array}{l}\text { Endemic, widespread in } \\
\text { forests in } S \text { Tasmania }\end{array}$ \\
\hline L. menalcas & 1 & - & - & $\begin{array}{l}\text { Endemic, rare (approx. } 20 \\
\text { specimens collected), wet } \\
\text { forests in SE }\end{array}$ \\
\hline \multicolumn{5}{|l|}{ Lycidae } \\
\hline Metriorthynchus sp. & 4 & 4 & - & Widespread \\
\hline \multicolumn{5}{|l|}{ Oedemeridae } \\
\hline species A (larvae) & 2 & 3 & - & \\
\hline \multicolumn{5}{|l|}{ Staphylinidae } \\
\hline species A & 1 & - & - & Widespread \\
\hline species B & 1 & - & - & Widespread \\
\hline \multicolumn{5}{|l|}{ Tenebrionidae } \\
\hline Adelium abbreviatum & 3 & 3 & _- & Wet forests \\
\hline Coripera deplanata & 4 & 2 & - & $\begin{array}{l}\text { Endemic(?), widespread in } \\
\text { forests and woodlands }\end{array}$ \\
\hline
\end{tabular}




\begin{tabular}{|c|c|c|c|c|}
\hline Species & $\begin{array}{l}\text { Old-growth } \\
(53 \text { logs })\end{array}$ & $\begin{array}{l}\text { Regeneration } \\
(52 \text { logs })\end{array}$ & $\begin{array}{c}\text { Difference } \\
\text { between sites* }\end{array}$ & Notes \\
\hline Licinoma commoda & 2 & 2 & - & $\begin{array}{l}\text { Widespread in forest and } \\
\text { woodland }\end{array}$ \\
\hline Meneristes australis & 2 & - & - & Wet forests \\
\hline $\begin{array}{l}\text { Unidentified (probably } \\
\text { several species) }\end{array}$ & 18 & 19 & NS & \\
\hline $\begin{array}{l}\text { (Superfamily Scarabeoidea) } \\
\text { species A (larvae) }\end{array}$ & - & 1 & - & \\
\hline $\begin{array}{l}\text { COLLEMBOLA } \\
\text { Neanuridae }\end{array}$ & & & & \\
\hline Acanthanura dendyi & 8 & 11 & NS & $\begin{array}{l}\text { Endemic, common in } W \\
\text { and SW }\end{array}$ \\
\hline Australonura wellingtonia & 7 & 8 & NS & Endemic, widely distributed \\
\hline Megalanura tasmaniae & 5 & 19 & $<0.01$ & Common in W and SW \\
\hline ?Pseudachorutes sp. & 2 & 6 & - & Unknown distribution \\
\hline Uchidanurinae sp. 4 & 1 & 3 & - & Specific identity uncertain \\
\hline Uchidanurinae sp. 5 & - & 1 & - & E distribution \\
\hline Womersleymeria bicornis & 4 & 2 & - & Common in W and SW \\
\hline
\end{tabular}

* The significance of differences in species occurrences from logs in the two areas (NS = not significantly different; $-=$ occurrence insufficient for analysis). Presence of beetle species was assessed from larvae, pupae and adults.

been eliminated from the old-growth forest. This raises the question as to what represents an experimental control. It is possible that there is no such thing as a pristine encalypt forest with a completely intact complement of invertebrates which can serve as a baseline. For this reason, studies on the effects of logging are probably best carried out by comparing an area before logging and at varying time intervals after logging.

Logs were chosen as a habitat to be sampled because of their importance to certain groups of endemic species and because of comments on the possibility of regeneration burns affecting their suitability for invertebrates (Greenslade 1985). However, many of the species sampled will not be totally dependent on logs. Many may simply use logs for shelter or be capable of feeding in other microhabitats (such as litter) in the absence of logs. This will almost certainly be the case for snails, centipedes and millipedes. Old, decayed logs appear to be the preferred microhabitat of the collembolans sampled (Greenslade, in press). Coleopteran species sampled vary in their dependence on logs. The Lucanidae were used by Greenslade (1985) as an example of a $\log$ dependent group containing many endemic species. Two species of lucanids (both endemic) were sampled in the present study. One occurred in both areas; for the other, known to be a rare species, one individual was found in the old-growth forest.

In the present study, two contiguous areas were selected as a control measure. It was assumed that the logged and old-growth areas had similar invertebrate faunas before logging occurred. However, after the first rotation of a large block of production forest is complete, it is possible that an individual coupe could become isolated from refuge areas. This may impede recolonisation of logged areas by those species with poor dispersal ability. Greenslade (1985) suggests that adversityselected species will predominate in old rotting logs. One of the characteristics of these species is their poor dispersal ability; the great majority are endemic with restricted distributions (Greenslade 1985) and are thus species whose conservation is of concern. Retention of unlogged and unburnt strips of forest throughout production zones may reduce the likelihood of fire-sensitive species and species with poor dispersal ability being adversely affected by logging operations. The Forestry Commission is at present investigating the implementation of such a system of wildlife habitat strips (Taylor 1990) and has commenced research to investigate their value for fauna conservation. 


\section{ACKNOWLEDGEMENTS}

Fieldwork, sorting and identifications of centipedes and millipedes were carried out by Bob Mesibov. The following people gave freely of their time 10 help with identifications: P. McQuilan (beetles), D. Bastaford (heetes), R. Kershaw (snails), P. Greenslade (collembolans) and Dr G. Bomemissra (bectlos). Alison Green allowed access to the Tasmanian Museum's millipede collection. John Traill and staff at the Geeveston district office of the Tasmanian Foresty Commission gave free access to files, map: and photographs. Petex McQuillan, Penny Greenslade, Bob Mesibov, Humphrey Elliott and Michael Brown provided constructive criticism of a previous draft.

\section{REFERENCES}

Greenslade, P., 1985: Conservation Priorities in Tasmamian Non-Marine Invertebrates. Unpubi. rep. Tasmanian National Parks and Wildife Service.

Grevenstade, P., in press: Notes on Austratian Uchidanurinate (Collembola Neanuridae) Proceedings of the Soll Zoology Symposium. Bangalue, India 7088.
Uommax. R.L., 1982: Diplopods. In Parker. S.P. (Ed I: SYNOISSIS AND CLASSIFICATYON OF IIVING ORCAN/SMS. MCGraw Hill New York.

Jwkti. C..W. 1984: Millipedes from Austratia. 7. The identity of the genus Lissodesnus Chamberint. with the description of four new species from Tasmania Diplopoda, Polydesmida, Dalomes midar . Pap Proc R. Sol. Tusm. IS: 85-102

MABKS, EN, 1972: A SUBMISSION TO HOUSE OP RAPRESLNTATUES SELACT COAMHITEON WHDIIFE CONSERVATION Maseript of evidence, Volume $X$ : 6363-6404.

Mesimov, R., 1986: A GUIDE TO TMSMANIAN CWNTIEOESS. The Author, Hohum.

Misuov, R., 1988: Tasmanian Onychoporia Unpubl rep. Tasmanian Department of Lands, Parks and Wildife, Hobart

NEW, T'R., 1984: INSECT CONSERVATION. AN AUSTRALIAN PERSPECTIVE. Dr W. Junk, Dordrecht.

SMITH, B.J. \& Kt:RSHAW, R.C., 1981: TASMANIAN LAND AND FRESHWATER MOLLUSCS. FaUna of Tasmania Handbook No. 5. University of Tasmania, Hobart.

TAYIOR, R.J., 1990: FAUNA MANUAL. Forestry Commission, Hobart.

(accepted 2 February 1990) 